\title{
Committing to endangerment: medical teams in the age of corona in Jewish ethics
}

\author{
Tsuriel Rashi $^{1}$
}

Accepted: 15 October 2020 / Published online: 19 October 2020

(c) Springer Nature B.V. 2020

\begin{abstract}
Doctors have been treating infectious diseases for hundreds of years, but the risk they and other medical professionals are exposed to in an epidemic has always been high. At the front line of the present war against COVID-19, medical teams are endangering their lives as they continue to treat patients suffering from the disease. What is the degree of danger that a medical team must accept in the face of a pandemic? What are the theoretical justifications for these risks? This article offers answers to these questions by citing opinions based on Jewish ethical thought that has been formulated down through the ages. According to Jewish ethics, the obligation to assist and care for patients is based on many commandments found in the Bible and on rulings in the Responsa literature. The ethical challenge is created when treating the sick represents a real existential danger to the caregivers and their families. This consideration is relevant for all dangerous infectious diseases and particularly for the coronavirus that has struck around the world and for which there is as yet no cure. Many rabbis over the years have offered the religious justifications for healing in a general sense and especially in cases of infectious diseases as they have a bearing on professional and communal obligations. They have compared the ethical expectations of doctors to those of soldiers but have not sanctioned taking risks where there is insufficient protection or where there is a danger to the families of the medical professionals.
\end{abstract}

Keywords COVID-19 $\cdot$ Coronavirus $\cdot$ Self-risk $\cdot$ Doctors $\cdot$ Jewish ethics

\section{Background: the danger to the medical teams}

The coronavirus (COVID-19) global epidemic, which broke out at the end of 2019, is similar to the earlier SARS-CoV-2 virus strain that passed from infected animals to humans and has already caused millions to be infected and hundreds of thousands of deaths. At first, most of the coronavirus morbidity was seen in China. However, from the middle of February 2020 the virus started to spread rapidly and by the middle of March had reached 150 countries and caused a worldwide panic. The World Health Organization declared it a pandemic at the beginning of March 2020. Some doctors and nurses have been seriously infected and tragically some have died. According to Chinese government statistics, more than 3000 doctors have been infected there, nearly half of

Tsuriel Rashi

Tsuriel.rashi@gmail.com

1 Ariel University, Ariel, Israel them in Wuhan, where the pandemic began. Li Wenliang, the Chinese doctor who first tried to raise the alarm about COVID-19, eventually died of it.

In Italy, the number of infected heath care workers is now twice the Chinese total, and the National Federation of Orders of Surgeons and Dentists has compiled a list of 170 who are known to have died. ${ }^{1}$ Medical teams also face the fear of bringing the disease home to spouses and children. Some Italian medical personnel are sleeping in separate rooms and even wearing surgical masks at home. Others have chosen to isolate themselves from their families completely, sending spouses and children to live outside the city or moving themselves into hotels.

At the end of March 2020, the Health and Hospitals Corporation, which runs New York City's public hospitals recommended transferring doctors and nurses at higher risks of infection-such as those who are older or have underlying medical conditions-from jobs interacting with patients

\footnotetext{
1 A constantly updated list of doctors who have died can be found on: https://portale.fnomceo.it/elenco-dei-medici-caduti-nel-corso-delle pidemia-di-covid-19/.
} 
to more administrative positions (Schwirtz, 30.3.2020). In Spain, nearly $14 \%$ of country's confirmed coronavirus cases are medical professionals (Benavides, 31.3.2020). On another front, the British Medical Association (BMA) has called the shortage of personnel protection equipment (PPE) across the National Health Services "totally unacceptable" and has warned that without proper kits some of the doctors treating patients with COVID-19 might die (Newman, 26.3.2020).

How should doctors and other medical personnel respond when required to treat patients for an infectious disease when there is a very real possibility that they themselves will be infected? How should health care systems deal with doctors who leave their shifts in hospitals in order to protect their lives and those of their families? There are serious and at present the urgent issues, but no country on earth has found appropriate answers. It is clear that it would be impossible to enact legislation that would oblige a doctors to report for work against their wishes. ${ }^{2}$ It is possible that doctors would prefer to quit their profession rather than risk their lives and those of their families in the cause of altruistic dedication. The delicate balance that has to be struck is between the duty to avoid unnecessary danger and the obligation to heal others. Jewish ethics deals extensively with the many aspects of this balance.

\section{The obligation to avoid danger and the permit to take risks in Judaism}

The Bible commands man to be careful and to protect himself: "Keep thee and keep thy soul" (Deuteronomy 4:9). This obligation is not an amorphous one but has been embodied in a range of specifics in the Bible and in Talmudic

\footnotetext{
2 Some medical associations have dealt with this only in the wake of the COVID-19 outbreak, but some addressed the issue several years ago during other epidemics. One of the associations that has updated its guidelines, for example, is the AMA. The American Medical Association (AMA) Code of Medical Ethics offered foundational guidance for health care professionals and institutions responding to the COVID-19 pandemic in Opinion 8.3, "Physicians' Responsibilities in Disaster Response and Preparedness." For further discussion, see: https://www.ama-assn.org/delivering-care/ethics/physicians -responsibilities-disaster-response-preparedness.

On the other hand, the Israel Medical Association (IMA) addressed the question in 2008 as to whether there is a limit to the medical commitment in a pandemic following the SARS outbreak, and the main points were put into the IMA's Code of Ethics. For further discussion, see: The Ethics Board: Rules and Position Papers, p. 50. Retrieved from: https://www.ima.org.il/userfiles/image/EthicalCode2018.pdf. In a position paper published in 2008 the IMA dealt with question: Is there a limit to the medical obligation in pandemic situations? The Ethics Board: Rules and Position Papers, pp. 144-145. Retrieved from: https://www.ima.org.il/userfiles/image/EthicalCode2018.pdf.
}

discussions over the years. One example that relates to the requirement that one must avoid unnecessary risk and not endanger others is the halakhic ruling about a railing. The biblical injunction is divided into the positive commandment to build a railing and the negative one to avoid creating an obstacle: "When thou buildest a new house, then thou shalt make a parapet for thy roof so that thou do not bring blood upon thy house, if any man should fall from thence" (Deuteronomy 22:8). According to the words of Rabbi Nathan in the Talmud (Baba Kama 15b), the commandment regarding a railing is not limited only to the railing, but any safety hazard that may cause danger must be removed: "How do we know that it is forbidden to raise a bad dog and not to put a rickety ladder inside the house? It is said, 'that thou bring not blood upon thy house' ".

Maimonides explained the biblical commandment to make a railing for the roof of the house and noted that it was a commandment of principle that constitutes a model for other cases:

There is no difference between a roof or anything else that is dangerous and likely to cause death to a person who might stumble. If, for instance, one has a well or a pit in his courtyard, he must build an enclosing ring ten handbreadths high or put a cover over it, so that a person will not fall into it and die. So, too, any obstruction that is a danger to life must be removed as a matter of positive duty and extremely necessary caution.

(Laws of Murderer and the Preservation of Life 11:4) ${ }^{3}$

According to Maimonides, this is not a voluntary instruction or simply good advice. When something is forbidden because it may cause harm, that prohibition should not be violated. In the section that followed, he ruled: "The sages have prohibited many things because they are dangerous to life. If anyone disregards them and says: 'What claim have others on me if I risk my own life?" or 'I do not mind this,' he should be lashed for disobedience (Laws of Murderer and the Preservation of Life 11:5).

However, there are crafts and jobs that, by their very nature, pose a degree of risk. The Bible commands that in the case of a hired worker, an employer must pay his salary on time: "In the same day, thou shalt give him his hire, neither shall the sun go down upon it; for he is poor and setteth his heart upon it - lest he cry against thee unto the LORD and it be sin in thee" (Deuteronomy 24:15). Regarding the words "and setteth his heart upon it," the Talmud says: "Why did the worker get on the ramp and risk his life? Was it not

\footnotetext{
3 This is not the only source that religiously justifies the duty to beware of unnecessary danger and not to harm others. For more on this subject, see Rashi (2020).
} 
because he wanted to receive his wages?" (Baba Metzia'a 112a).

According to the Talmud, workers put themselves at risk in the expectation that they will get their pay just as they deserve, which is the only reason that they are willing to do so and the justification for them taking such risks. In the words of the great Talmudic commentator Rabbi Shlomo Yitzhaki (Rashi): "He gave of himself for the sake of his employer: for him he risked himself to mount a high rampart or hang from a tree when he climbed up to harvest olives or pick dates, and he actually risked his life, lest he fall from the rampart or from the tree." That is, for lack of choice and to earn a livelihood, an individual is allowed to take risks in his work, when the essence of that work is engaging with dangerous things or precarious situations.

What does the Halakha say about avoiding risk if an individual has a choice about endangering himself-whether for a living or for engaging in a leisure activity? A rich man once asked the rabbi of Prague, Rabbi Yechezkel Landa, whether it is permissible to go on a hunting trip just for pleasure, the rabbi replied that hunting should be banned (apart from the issue of cruelty to animals) because it involves unnecessary danger: to hunt one must go into a forest, where wild beasts roam and thus expose themselves to great danger. His reasoning was based on what the Bible says about Esau: "And let there be a man who knows hunting (Genesis 25: 27), and yet when Jacob asked him for the firstborn rights he replied " 'Behold, I am about to die; and what profit shall I have from the birthright?"' (Ibid, 25: 32). That is, it is clear that hunting can be life threatening. If so, "How can a Jewish man put himself in the place of regiments of evil beasts"?

Rabbi Landa then qualified his ruling and added that whoever is poor and must hunt for a living, the Torah allows him to do so because everything a person does for his livelihood is without choice, so like any worker, he is allowed to hunt as he does so for his livelihood (Responsa Noda be'Yehudah, Second Edition - Yoreh De'a Chapter 10). However, the Judaic religious injunction that makes it obligatory to heal others changes the norms when one talk's about individuals who practice medicine: the question then becomes not whether they are allowed to endanger themselves, but rather the permissible degree of that danger.

At this point it is important to note that there is no word in Hebrew for altruism, so the concept as such does not exist in the Jewish world. A similar term in Hebrew is the word for charitable giving, which is one of the foundations of Judaism, as is said in the Mishnah Tractate Avot: "The world stands upon three things: the Torah, the Temple service, and the practice of acts of piety" (Chapter 1, Mishnah 2 ). Although altruism in its philosophical connotations is not fully expressed in the Jewish world, there are many commandments in the Bible that call for caring for others.
Among them are those that require concern for weaker populations, including the poor, orphans, and widows (e.g., "a widow and an orphan will not be punished" Exodus 21:21), which are all embodied in the commandment to give charity, as well as in more general verses, for example: "And love thy neighbor as thyself" (Leviticus, 19:18). Yet Judaism does not condone excessive devotion to others at the expense of oneself. $^{4}$

\section{The obligation in Jewish ethics to heal others}

The Babylonian Talmud (Tractate Sanhedrin 73A) relates to the basic obligation to save the life of one's fellow in danger based on the biblical injunction: "Where is it written that someone who sees his fellow drowning or being swept away in the river or being attacked by bandits is obliged to save him? We are taught: "Do not do anything that endangers your neighbor's life" (Leviticus 19:16).

Maimonides [Moses ben Maimon (1138-1204) also known as Rambam], the greatest legal arbiter in Jewish history, expanded on the words of the Talmud and ruled: "Anyone who is able to save, yet does not save ... So too one who sees his friend drowning in the sea or bandits or a dangerous animal attacking him and is able to save him or hire others to save him but he does not... as in any similar case also transgresses "do not stand idly by your neighbor's blood"(Mishneh Torah, Laws of Murder and Protecting Life, 1:14). That is, according to Rambam, there is a Torah commandment to save one's fellow at the cost of one's time and/or money and even at the risk one's own life. Thus, the requirement to save is not an option, but rather an ethical and religious obligation.

The question that begs to be asked is if this mitzvah has be fulfilled even at very serious risk of endangering the life of the rescuer? Rabbi David Ben Shlomo Ibn Zimra (1479-1573), also known as Radbaz after the initials of his name was one of the Middle Age halakhic arbiters who addressed this issue. The chief rabbi and the religious leader of Egyptian Jewry and the author of more than 3000 responsa (halakhic decisions) as well as several scholarly works, he was once asked a hair-raising question: "What should a Jew do if a government official says, 'Let me cut off one of your limbs in such a way that it will not cause your death, or I will kill your friend!'” (The Radbaz, Responsa of the Radbaz, Vol. 3, Chap. 627). After giving several reasons for his answer, Radbaz ruled that even though there was only a possible risk of endangering life, someone who agreed

\footnotetext{
${ }^{4}$ For more information, see: Neusner (2006) and Neusner and AveryPeck (2005).
} 
to lose a limb in such a case was "foolishly pious"- that is, someone who goes far beyond his obligation basing his actions on a distorted religious interpretation. In a further responsum, that appears to contradict his first answer the Radbaz clarified other aspects of the matter, writing that a man is only obliged to save his fellow if there is no danger to himself. An example of this kind of rescue is to wake up someone sleeping under a wall that is tilting or providing information that can save a life. Nonetheless, he reiterated his contention that a man is obliged to save his fellow even when there is the possibility of danger to himself. For example, if he sees someone drowning in the sea or being attacked by bandits or by a wild animal-all of which include possible danger to the rescuer-in each case he is still obliged to save his fellow.

Rabbi Ovadia Yosef (1920-2013), the Sephardi Chief Rabbi of Israel from 1973 to 1983, was the spiritual leader and president of the Council of Sages. The recipient of the Israel Prize for Torah Literature in 1970, he is considered by many to be the most prominent Sephardic rabbi of his generation and one of the most important jurists of the last 500 years. In his book Yachveh Daat (Part 3, Section 84), he explained the contradiction between the two rulings: in Radbaz's first ruling, where someone endangering himself to save another is called "foolishly pious," he was referring to a case where the likelihood of danger was $50 \%$ or more, whereas the second responsum dealt with one in which there was less likelihood of imminent danger.

This distinction based on the degree of danger is a consideration that applies to everyone, not just to an individual whose is professionally dedicated to saving lives. Obviously, it becomes doubly important when it is concerns someone in the medical profession. ${ }^{5}$ In any case, it can be said in principle, that when rescue requires that the rescuer put himself into serious danger, according to Jewish ethics there is no obligation to save, that is, it is above and beyond the call of duty to endanger oneself to save others. If the danger to the rescuer is extreme, he would be foolish to risk it, but if the danger to himself is less than extreme, there is no justification to refuse to help. If a person wishes to save someone who is only in slight danger, he is not allowed to endanger himself at all.

\section{Jewish ethics in regard to the danger to doctors treating infectious diseases}

Is it permitted for a doctor to place himself and his family in danger? Is a doctor obliged to work under hazardous conditions even if does not wish to do so? It is clear that when we

\footnotetext{
${ }^{5}$ For further discussion of the constant obligation of a doctor to help others and to heal them, see Blaives (1999).
}

deal with danger to doctors, we must assume that they will take all required care for themselves when treating patients.

Apparently, individuals who chose medicine as a profession and earns their livings practicing that profession cannot argue that they do not wish to endanger themselves in pursuing that work. The fact is that by joining the medical profession, they undertook to engage in healing, which sometimes includes a certain degree of danger in order to save lives, in the same way that firefighters endanger their lives to rescue people from a burning building or policemen risk themselves to fight crime in the streets. The question is whether it is permitted for doctors to take a step back when confronted with an infectious disease that places them in greater danger than during the normal course of their work. Are they permitted to risk the possibility of serious danger?

Rabbi Eliezer Yehuda Waldenberg (1915-2006), known as Tzitz Eliezer for his broad-scope twenty-one-volume treatise that covers a wide range of halakhic issues and a long-serving chaplain at the Sha' are Zedek Medical Center in Jerusalem, was a leading authority on medicine and Jewish ethics. A member of the Great Rabbinical Court and the recipient of several awards for his writings, he was once asked whether a doctor was obliged or at least was permitted to expose himself to possible danger to treat a patient with an infectious disease. In his detailed response, he wrote:

A doctor is not obliged to endanger himself to save a patient seriously ill with an infectious disease if he has no way to protect himself and providing treatment will endanger himself.... However,... I think one can say that this is a doctor way of life. He is acquainted with the diseases that afflict people, he gives them the help that they require, and if he would not there would be enormous chaos among the sick and healthy alike. Therefore, in such a case, since it is the way of the world ${ }^{6}$ nothing in this danger would make healing the sick be

\footnotetext{
${ }^{6}$ Practically, Jewish ethics follows the prevailing standards in the secular world. Especially when it comes to medicine and other areas of daily life, Halakha recognizes accepted professional and administrative standards as well as the norms adopted by civilized societies. Called "the way of the world" in Halakha, these criteria can include certain laws, regulations, and/or social norms (Barilan 2019, p. 6). Barilan showed that it is part of the religious rulings in several different cases, such as: What is the proper moral behavior in relation to kidnappers who demand excessive ransom for the hostages (Brailan 2019, p. 107)? What are the criteria for a doctor's professionalism and what are the moral expectations from him (Brailan 2019, p. 125)? And a further issue: What is the position regarding the sale of organs (Brailan 2019, p. 159)?

A most interesting contemporary issue concerned the fact that many women whose medical condition requires the use of contraception prefer the self-risk because of their desire for children. In light of the halakhic tendency to agree with "the way of the world," Rabbi Shlomo Zalman Auerbach (1999, Chapter 82, Sect. 12) did not examine the reasons for these women's willingness to endanger themselves for the sake of having children and did not ask whether it is morally acceptable. This was a landmark ruling as Rabbi Shlomo Zalman
} 
considered put himself in the prohibition of danger to save his fellow. Furthermore, it seems in my humble opinion that since a doctor treats the sick for his livelihood, he is accordingly permitted to endanger himself, just as the Torah permits entering dangerous places for one's living, as it is written "And you will be guilty of sin."... That it is permitted for someone... to go into dangerous places where he might get killed for his livelihood... and if so it is the same rule for a doctor working for his living, especially if according to the law of the land if he does not do so and is negligent in his treatment of the sick he will forfeit his license and lose his income.

... From everything stated it appears clear that it is permitted for a doctor to endanger himself to treat those sick with infectious diseases of all sorts and in every way. And it will be deemed an enormous mitzvah [good deed] to do so.

(Responsa Tzitz Eliezer, Part 9, Section 17 - Essay on Health on the Sabbath, Chap. 5).

Thus, in Rabbi Waldenberg's opinion there is no prohibition on doctors endangering themselves, and they would certainly not be called foolishly pious if they provide medical assistance. Therefore, it is permitted for doctors to treat patients with infectious diseases, provided that they take the necessary precautions for such work. This ruling was based on the fact that infectious diseases are generally not certain to endanger the caregiver and the ethical and religious obligation in Judaism to heal does not distinguish between an infectious and a noninfectious disease.

Furthermore, according to Rabbi Waldenberg, since doctors are engaged in their professions and thereby earning their livelihoods, they are permitted to endanger themselves to ensure the continuation of those livelihoods and to

\footnotetext{
Footnote 6 (continued)
}

Auerbach (1910-1995), the head of the Kol Torah Yeshiva in Jerusalem, was considered one of the most important of the twentiethcentury Orthodox rabbis. An acknowledged halakhic authority on technological and medical issues, he wrote extensively on these subjects. Among his major initiatives were scientific studies to establish halakhic principles to determine the moment of death according to Judaism.

Rabbi Auerbach's ruling is a telling example of the problematic aspect of the openness of Halakhah to professional and social standards. Rabbis generally prefer not to criticize a problematic practice and sometimes even rely on this practice to support an even more problematic custom. They do not try to critically examine the "way of the world"- public conduct and the biomedical establishmentbut rather rely on common practices even if these have been subjects of considerable public and academic criticism, and they even relate to these problematic practices to render creative and bold halakhic extrapolations (Barilan 2019, p. 188). undertake to work that involves danger, such as professionals who are required to climb poles, work high places or deal with dangerous substances. All the more so, may doctors endanger themselves for their livings in order to save human life. Moreover, as doctors undertook to do so when they accepted their posts, they are obliged to fulfill that undertaking. In respect to the question of whether there is a difference between doctors and others on the issue of endangering oneself to save lives, Rabbi Waldenberg ruled that doctors have an extra obligation to heal the sick, even as they are aware of the danger to which they are exposed. However, there are others who hold that doctors is not required to endanger themselves by treating patients with infectious diseases.

Rabbi Yitzhak Zilberstein (1934-), an Ultra-Orthodox rabbi, a halakhic arbiter, and a specialist in the laws concerning doctors and medicine. He has authored a number of books dealing with Halakhah and medicine and teaches a monthly class to physicians, both religious and secular, during which he discusses various issues from the world of medicine and the relevant position of ethics and Jewish law. $\mathrm{He}$ is on the rabbinical committee of the Mayanei Hayeshua Medical Center in the Ultra-Orthodox City of Bnei Brak, a hospital that is run strictly according to the rules of Halakhah. In any case where there is halakhic doubt, the medical staff calls upon the halakhic advisors, headed by the hospital rabbi, and the doctors proceed only the advisors have rendered a decision.

Rabbi Zilberstein has also been a member of the Council of Torah Scholars, the religious leadership of hundreds of thousands of Ultra-Orthodox Jews, for about ten tears. When once asked whether a woman doctor in the early stages of pregnancy who was called upon to treat a patient with rubella was obliged to meet that call, he ruled that she should be excused from treating that patient. His reasoning was that if she became infected with German measles there was a $20 \%$ chance that she would miscarry or give birth to a baby with a deformity. As there were other doctors available, there was no reason for her to have to deal with the rubella patient. Furthermore, when she chose to become a doctor, she surely did not undertake to endanger herself a pregnancy, which would also endanger the fetus (Zilberstein 1994).

Contrary to the opinions of Rabbi Waldenberg and Rabbi Zilberstein, who both addressed cases related to treating a single patient with an infectious disease, the picture changes when dealing with an epidemic, as does consideration of the issue from the viewpoint of Jewish ethics.

Rabbi Shmuel HaLevi Wosner (1913-2015), a prominent Ultra-Orthodox rabbi and chairman of the Rabbinical Committee of the Maayanei Hayeshua Medical Center, was asked how a doctor should respond when called to treat someone with a dangerous infectious disease, especially during an epidemic, and whether it was permitted for the doctor to 
leave his post. In his response, Rabbi Wosner based himself on the opinions of Rabbi Akiva Eger (1761-1837), who wrote the most comprehensive and in-depth instructions with respect to actions during an epidemic some 200 years ago during an outbreak of cholera in Poland when he served as a rabbi there.

Originally from Posen, Germany, Rabbi Eger, who was an outstanding early nineteenth-century Talmudic scholar, an influential halakhic decisor, and a foremost leader of European Jewry, instituted regulations that greatly helped to prevent the spread of the disease, including directives to isolate areas of infection. He appointed a committee that would be responsible for hygiene in public places and for raising awareness among the people. He ensured that the committee would fund cleaning services for the alms houses and distributed posters concerning the religious obligation to protect one's health by boiling drinking water and pursuing personal hygiene. On one occasion, he wrote: "I have already warned time after time that their behavior should be... as organized and adjudged by the doctors... and not to violate what they say" (Letters of Rabbi Akiva Eger 81, 83, Novellae of Rabbi Akiva Eger, Nedarim 39). The regulations he instituted, which helped stop the cholera epidemic, earned him a letter of appreciation from the King of Prussia, Friedrich Wilhelm III. ${ }^{7}$

Thus, Rabbi Wosner ruled as follows:

A priori it is forbidden for doctors who are able help to run away and abandon their positions but they should follow the medical guidelines of the times and take all possible precautions so as not to become infected. The proof is from the ruling of Rabbi Akiva Eger at the time of a cholera epidemic in the city of Posen. On that occasion, Rabbi Eger wrote that people who can treat the sick will be often in the same room as the sick person and that he himself had hired people to assist in the care of the city's patients but he noted that such helpers should immediately call for a doctor at need. (Responsa Shevet Halevi, Part 8, Section 251).

In other words, doctors have to be part of society's attempts at corrective action. That is their role-to save life and to relieve the suffering of the sick. Thus, they have an obligation to serve in dangerous situations in order to save others.

Rabbi Asher Weiss (Israel, 1953-), a rabbi of the Sanz Hasidic sect, the current chaplain of Shaare Zedek Hospital in Jerusalem, and one of the most important contemporary

\footnotetext{
${ }^{7}$ For the text of Friedrich Wilhelm III's letter published in the press, see Blum (1938). Rabbi Eger's perspective regarding his actions to prevent the spread of cholera and his instructions to the Jewish public at that time, including detailed descriptions of the epidemic and actions for public hygiene can be found in Letters of Rabbi Akiva Eger, letters 146-148.
}

rabbis in the city, has also referred to the dangers that doctors have to accept during an epidemic. He bases his opinion on the nature of the behavior of medical teams in principle and the ethical expectations society has of them, noting that there were many rabbis in the eighteenth century who wrote that the situation is different in time of war: the demands are different, the expectations are higher, and the dangers to which front-line responders are exposed are exceptional in comparison with normal times. In 2012, Rabbi Weiss wrote:

It appears that it is not just soldiers serving in the army in time of war, but everyone carrying out a vital role that includes the saving of life, such as policemen, firefighters, divers whose job is to save citizens lost at sea, security personnel for government officials, and others. All these are obliged to risk their lives to save the many and sometimes even to save a single person.

The basis of this contention [that is the underlying idea behind this approach] is that in the natural course of the life of a people there is sometimes the need for war, and without sacrifice there is no victory in war. Therefore, it is clear to us that as it is permitted to endanger oneself in war, similarly, in a developed society that makes every effort to heal the sick and to save those in danger, everyone is required to do everything possible to minimize the threat. It is permitted for those who have taken upon themselves tasks of saving and rescue to endanger themselves to carry out their jobs and to save their fellows. Accordingly, it appears that doctors too are permitted and even required to endanger themselves to a certain point to heal the sick, even those with infectious diseases.

(Responsa Minchat Asher, Part 3, Section 122).

That is to say, in time of war just as we expect soldiers to endanger their lives beyond what is normally required, during an emergency, we also expect the same from those in other positions committed to saving lives, such as policemen and firefighters. Part of the life of a people in any country is counting on professionals taking calculated risks in demanding circumstances. Therefore, it is possible and even required for doctors to endanger themselves by taking calculated risks during an epidemic as military ethics demands of soldiers in time of war.

\section{Rabbinical guidelines for doctors treating patients infected with the coronavirus}

With the outbreak of the novel COVID-19, Rabbi Weiss was asked by a member of a medical team whose wife was ill with multiple sclerosis, a serious disease that impairs the immune system, whether he should continue to work or 
leave his post out of concern that he might be placing his wife in danger. The Rabbi mentioned the ruling above that, in principle, the matter depends on the degree of danger to which one is exposed as compared with the degree of danger facing those whom he serves. Thus, a medical professional, who is permitted to minimally endanger himself to save others, is not allowed to endanger his wife, who is at high risk because he wants to help someone else. According to Rabbi Weiss, this was said primarily in light of the fact that there are others who can help in the fight against the epidemic, and if that doctor becomes infected the likelihood that he will endanger his wife is too high (Weiss 2020, pp. 18-19). The Rabbi's words referred to a private case, but, in principle, the rabbis have generally ruled that doctors must accept a degree of risk when treating corona patients.

Rabbi Yuval Cherlow (1957-), a Modern Orthodox rabbi and one of the founders of Tzohar, an organization of religious Zionist Orthodox rabbis in Israel, has served as a member of the Helsinki Committee for the Approval of Clinical Trials on Humans and the Israeli Committee for the Selection of Fetus Gender. He has written extensively about professional ethics in general and medical ethics in particular. In answer to the question of how doctors who are required to treat corona patients should act, he noted that, on the one hand, Jewish law holds that a person is not obliged to expose himself to danger in order to save his fellow, as Radbaz ruled. Based as it is on one of the fundamentals of Jewish law: "Your life takes precedence over the life of your fellow," and it does not demand what cannot be demanded, ${ }^{8}$ this also holds true in cases of saving lives. On the other hand, in taking the Hippocratic Oath, which is the basis for the obligation, doctors have committed themselves to care of the other, to heal him, and to and relieve his pain. Without this undertaking they would not have been certified. Thus doctors may not enjoy their status as physicians and yet avoid the responsibilities incumbent upon them. Beyond that, according to Jewish ethics, if one has the ability to heal it is not an option but rather an obligation, so doctors have a religious obligation to heal the sick who need their help.

In the end, Rabbi Cherlow adopts Rabbi Weiss's approach: in the same way we require soldiers to endanger themselves in time of war, so, too, we have to demand

\footnotetext{
8 The source of this saying is in the Babylonian Talmud (Treatise Bava Metsia 62B), which discusses the hypothetical case of two on a journey, and one of them has a canteen of water. If they both drink, they will both die, and if one of them drinks, he will survive and reach a town. Two of the Talmudic sages of the first century CE disagreed among themselves: Ben Petora ruled it was better if both drank and then died, that one should not see the death of his friend. Rabbi Akiva disagreed and said "that they may continue to live among you": Your life takes precedence over the life of your fellow. Clearly, from the rulings of the overwhelming majority of legal arbiters across the ages, Jewish law follows Akiva.
}

the same from medical personnel during crises. We have to consider the fight against corona as a national struggle that requires public commitment. Accordingly, each of us, in his/ her turn, is required to endanger him/herself to save others, even if the other is only potentially in danger:

This is one of the most fundamental bases of the relationships between society and government and individuals. This is not just a matter of a commitment toward one patient or another, but if they are doctors, they are the only ones capable of dealing with the challenge - if they do not heal there will be a general social disaster; therefore the situation is very similar to the status of a soldier.

(Cherlow 2020).

In another response to the question of whether medical teams must put themselves into situations of danger, the Rabbi of the Great Synagogue of Tel-Aviv, Yitzhak BarZe'ev, noted that there is a built-in tension between the biblical injunctions to distance oneself and to protect oneself from danger: "Therefore guard yourselves very carefully" (Deuteronomy 4:15), ${ }^{9}$ which calls for protecting one own's health, and the verse "The Lord protects the unwary" (Psalms 116:6), which expresses faith that God shields from common ordinary dangers. According to Rabbi Bar-Ze'ev, the balance is the recognition that alongside the general obligation to keep one's distance from the risk of any danger, it is nevertheless sometimes permitted for a person to endanger himself and to rely on God for protection, for instance as in road travel (despite the high number of road accidents), etc., or when someone endangers oneself to save one's fellow.

Thus, according to Rabbi Bar-Ze'ev, as long as the medical teams follow the safety instructions of the health authorities, as they are dealing with saving lives and the well-being of the public, it is not just permitted for them to endanger themselves, but they are thereby performing a great mitzvah, of which it is said "Anyone who saves one Jewish life is as though he has saved the whole world" (Bar Ze'ev 2020).

\section{Conclusion}

Doctors have treated the sick for thousands of years, often at the risk of their own health and well-being, but with every new epidemic societies re-examine the ancient issue of permissible risk. Jewish ethics establishes criteria whereby it is permitted for a person to endanger his life in order to save others.

\footnotetext{
${ }_{9}$ However, the verse in its biblical sense does not deal with protecting a person's physical health. Having said which, over the years, various rabbis and foremost among them the Rambam have regarded the verse as a call to protect people's health.
} 
It is clear that hospitals have to treat patients with infectious diseases because it is inconceivable from a public point of view that these patients be left to die. A low level of danger should not prevent a doctor from treating infectious patients (just as anyone else whose profession involves rescuing others from dangerous situations puts himself in danger); however, a rescuer must access the correct information and be intellectually honest about balancing the risks and the benefits of his/ her actions.

Unfortunately, in the case of medical professionals, the necessary information is not always available when the need for treatment arises. From the foregoing rabbinic opinions, we can conclude that just as a person does not have to be overly careful when the lives of others are at stake, there is also a limit to the degree of permissible risk. Doctors are expected to accept higher levels of risk than others because of the nature of their work, but they must still take precautions to minimize the risk to their lives. Medical personnel who can take all the usual protective measures but still do not want to treat the sick cannot continue to work, and thus must resign. Thus, there is an essential reasoning, as well as ethical considerations that to oblige doctors to continue to work and to endanger themselves when treating patients with infectious diseases.

At the end of March 2020, the Chief Rabbi of the United Hebrew Congregations of the Commonwealth, Rabbi Ephraim Mirvis, introduced a coronavirus-themed prayer. The prayer, which can be recited at any time, praises "doctors, nurses, all healthcare professionals and key workers, who tirelessly seek to heal and help those affected, while in doing so put themselves at risk." It calls on members of the public to open their "hearts" and extend their "hands in generosity to guarantee that the physical distance this virus creates between us will be bridged with compassion and kindness" (Frot, 23.3.2020).

This article was written during the 2020 corona pandemic. Let us hope that by the time it is published the danger will be over. We pray for the good health of the medical teams around the world who are risking their own lives for all of us.

\section{Compliance with ethical standards}

Conflict of interest The authors declare that they have no known competing financial interests or personal relationships that could have appeared to influence the work reported in this paper.

\section{References}

\section{Bible}

The Schottenstein Edition Talmud Bavli (1990-2012). New York: Artscroll.

Auerbach, Shlomo Zalman. 1999. Responsa Minchat Shlomo 2. Jerusalem: Otzrot Shlomo Institute.
Barilan, Yechiel Michael. 2019. Jewish Bioethics: History, Halakhah and Israeli Law. Jerusalem: Magnes Press.

Bar Ze'ev, Isaac. 12.3.2020. Should Medical Teams Treating Corona Patients Be at Risk? https://judaism.walla.co.il/item/3346047 (in Hebrew). Accessed 25 Mar 2020.

Benavides, Lucia. 31.3.2020. Spain's Health Staff are Catching the Coronavirus as Protective Gear Runs Short. https://www.npr.org/secti ons/coronavirus-live-updates/2020/03/31/824654965/spains-healt h-staff-are-catching-the-coronavirus-as-protective-gear-runs-short . Accessed 25 Mar 2020.

Blaives, Avrohom. 1999. Journal of Halacha and Contemporary Society XXXVIII. https://www.daat.ac.il/daat/english/journal/blaives-1.htm. Accessed 25 Mar 2020.

Blum, Saul. 1938. Rabbi Akiva Eger's Life: His Life and His Actions. Warsaw: Blum (in Hebrew).

Cherlow, Yuval Cherlow. 12.3.2020. Does a Doctor Have to Take the Risk of Treating the Patient? https://ethics.tzohar.org. $\mathrm{il} / \% \mathrm{~d} 7 \% 94 \% \mathrm{~d} 7 \% 90 \% \mathrm{~d} 7 \% 9 \mathrm{~d}-\% \mathrm{~d} 7 \% \mathrm{a} 8 \% \mathrm{~d} 7 \% 95 \% \mathrm{~d} 7 \% \mathrm{a} 4 \% \mathrm{~d} 7 \% 90-$ $\% \mathrm{~d} 7 \% \mathrm{a} 6 \% \mathrm{~d} 7 \%$ a8 $\% \mathrm{~d} 7 \% 99 \% \mathrm{~d} 7 \% 9 \mathrm{a}-\% \mathrm{~d} 7 \% 9 \mathrm{c} \% \mathrm{~d} 7 \% 94 \% \mathrm{~d} 7$ $\%$ a1\%d7\%aa\%d7\%9b\%d7\%9f-\%d7\%9b\%d7\%93\%d7\%99$\% \mathrm{~d} 7 \% 9 \mathrm{c} \% \mathrm{~d} 7 \% 98 \% \mathrm{~d} 7 \% \mathrm{a} 4 \% \mathrm{~d} 7 \% 9 \mathrm{c}-\% \mathrm{~d} 7 \% 91 \% \mathrm{~d} 7 \% 97 \% \mathrm{~d} 7 \% 95 \% \mathrm{~d} 7$ \%9c\%d7\%94/ (in Hebrew). Accessed 25 Mar 2020.

David Ben Zimra Responsa. n.d. Venice: Meir De Zara Press (in Hebrew).

Eger, Akiva. 1994. Letters of Rabbi Akiva Eger. Jerusalem: Da'at Sofer Institute (in Hebrew).

Eger, Akiva. 1969. Commentaries on the Tractate Nedarim. Jerusalem: Igud Bnei Hayeshivot (in Hebrew).

Frot, Mathilde. 23.3.2020. Bless the Doctors': Chief Rabbi Unveils Coronavirus Prayer to Recite at Home. https://jewishnews.timesofisrael. com/bless-the-doctors-chief-rabbi-unveils-coronavirus-prayer-torecite-at-home/. Accessed 25 Mar 2020.

Maimonides, Moses. 1954. The Code of Maimonides (Mishneh Torah). Trans. Herbert Danby. New Haven: Yale University Press.

Neusner, Jacob. 2006. Altruism in Judaism. In Encyclopedia of Judaism (Consulted online on 20 August 2020). https://doi.org/https://doi. org/10.1163/1872-9029_EJ_COM_0004.

Neusner, Jacob, and Alan J. Avery-Peck. 2005. Altruism in Classical Judaism. In Altruism in World Religion, ed. Jacob Neusner and Bruce Chilton, 31-52. Washington, DC: Georgetown University Press.

Newman, Melanie. 26.3.2020. Covid-19: Doctors' Leaders Warn that Staff Could Quit and May Die over Lack of Protective Equipment. BMJ 2020: 368. https://www.bmj.com/content/368/bmj.m1257. Accessed 25 Mar 2020.

Rashi, Tsuriel. 2020. Jewish Ethics Regarding Vaccination. Public Health Ethics. https://doi.org/10.1093/phe/phaa022.

Schwirtz, Michael. 30.3.2020. Nurses Die, Doctors Fall Sick and Panic Rises on Virus Front Lines. https://www.nytimes.com/2020/03/30/ nyregion/ny-coronavirus-doctors-sick.html. Accessed 25 Mar 2020.

Waldenberg, Eliezer. 1984. Tzitz, Eliezer. Jerusalem: Waldenberg (in Hebrew).

Wosner, Shmuel HaLevi. 2002. Shevet Ha-Levi. Bnei Brak: Wosner (in Hebrew).

Weiss, Asher. 2012. Minchat Asher. Jerusalem: Minchat Asher Institute (in Hebrew).

Weiss, Asher. 2020. Minchat Asher: Collection of Lessons and Responses, Letters and Articles Related to the Corona Epidemic. Jerusalem: Minchat Asher (in Hebrew).

Yosef, Ovadia. 1994. Yechaveh Da'at. Bnei Brak: El Hamayan (in Hebrew).

Zilberstein, Isaac. 1994. How Much Does One Have to Risk Himself to Save Others. Assia 7: 3-9 (in Hebrew).

Publisher's Note Springer Nature remains neutral with regard to jurisdictional claims in published maps and institutional affiliations. 